\title{
Electrophysical properties of nanoporous cerium dioxide-water system
}

\author{
V. I. Biletskyi ${ }^{1}$ - V. V. Bogdanov ${ }^{1}$ Yu I. Boyko ${ }^{1} \cdot$ R. V. Vovk $^{1}$ - G. Ya Khadzhai ${ }^{1}$ \\ I. L. Goulatis ${ }^{1}$ A. I. Chroneos ${ }^{2}$
}

Received: 17 August 2016/ Accepted: 1 October 2016/Published online: 7 October 2016

(c) The Author(s) 2016. This article is published with open access at Springerlink.com

\begin{abstract}
The impedance of nanoporous cerium dioxide with adsorbed water is investigated in the frequency range $10^{3}-10^{4} \mathrm{~Hz}$ at temperatures near the water-ice phase transition. Here we show that the manifestation of impedance peculiarities at phase transition is caused by the dielectric constant of the matrix.
\end{abstract}

\section{Introduction}

In porous materials, including a number of biological systems and fuel cell membranes, water is contained in small volumes [1-4]. The structure and the dynamics of the water in a confined space varies considerably compared with conventional "bulk" water and this is manifested in particular in the electrical transport processes. In these systems, proton transport and mobility is comparable to electron mobility in solids. In liquid water the hydrogen energy bond in the second hydration shell of the $\mathrm{H}_{3} \mathrm{O}^{+}$ complex is less than $\sim 0.1 \mathrm{eV}$. This leads to the "estafette" water conductivity mechanism (i.e. protons are transferred over the hydrogen bonds) [5].

When changing the relative humidity from 10 to $100 \%$ the resistivity of nanoporous oxides decreases by several orders of magnitude due to the increase of the ionic conductivity, and the specific capacity increases due to the high value of the dielectric constant of water. This allows

A. I. Chroneos

alexander.chroneos@imperial.ac.uk

1 Physics Department, V. Karazin Kharkiv National University, Svobody Sq. 4, Kharkiv 61022, Ukraine

2 Faculty of Engineering, Environment and Computing, Coventry University, Priory Street, Coventry CV1 5FB, UK the use of such materials as a basis for the creation of highly sensitivity humidity sensors.

Lowering the melting and the crystallization temperatures of water, is a well-known phenomenon that has been widely studied by calorimetry [6], nuclear magnetic resonance [7], neutron and X-ray diffraction [8] and other methods. In previous studies there is some data about electric transport for a number of porous matrix-adsorbed water systems, at temperatures near the ice-water phase transition, where the conditions of protons transfer in the system of hydrogen-bonded water molecules vary greatly [9-12]. Such studies were carried out for powdery nanoporous matrices based on aluminum oxide [9, 10], titanium oxide [9], silicon oxide [11], nanoporous silicates [12] and graphene oxide films [13].

Cerium dioxide is a material that is widely studied as it is an important electrolyte for intermediate temperature solid oxide fuel cells [14-16]. The efficient operation of these devices necessitates high oxygen self-diffusion rates in the electrolyte and cathode and as such doped $\mathrm{CeO}_{2}$ is beneficial as compared to traditional electrolytes such as $\mathrm{ZrO}_{2}$ [17-21]. Here we consider matrices of powdery cerium dioxide, which is a multifunctional material for today's high-tech industries [22-24]. Additionally, cerium dioxide is used as the abrasive material in the optical industry, in integrated circuits, UV filters, solar batteries, and gas sensors. A very important application of cerium dioxide is in catalytic afterburning of exhaust gases systems of vehicles and the conversion of carbon monoxide.

In the transition to the nanocrystalline state, cerium dioxide significantly changes its physical and chemical properties. This is due to the fact that the reduction of the size of $\mathrm{CeO}_{2}$ nanoparticles leads to a noticeable increase in the proportion of cerium in the $\mathrm{Ce}^{3+}$ state. This reversible change in the oxygen non-stoichiometry causes the unique 
opportunity to use $\mathrm{CeO}_{2}$ in regeneration systems and to detect gas media. In the present study we consider the adsorption properties of the system nanosized powder $\mathrm{CeO}_{2}$-water in the temperature range of +50 to $-50{ }^{\circ} \mathrm{C}$, which is the temperature interval for practical application.

\section{Experimental methodology}

For the electrical-physical experiments $\mathrm{CeO}_{2}$ nano-disperse powder with grain size of $\sim 20 \mathrm{~nm}$ was used. A portion of powder was placed in a cylindrical measuring cell, the body of which was made of electrical porcelain and the contacts were made of copper pistons. The sample was a compacted powder tablet of $5 \mathrm{~mm}$ in diameter and thickness of $1.5 \mathrm{~mm}$. The sample temperature was monitored with an accuracy of $\sim 0.2 \mathrm{~K}$ by a copper-constantan thermocouple, placed inside the copper piston. Prior to the measurements, the sample was kept in a saturated water vapor to stabilize the indications of the resistance measuring instrument.

The temperature of the measuring cell was changed by metered blowing of the camera with the cell pairs with nitrogen from a cryogenic Dewar flask in the temperature interval below $273 \mathrm{~K}$ or by heating the chamber above 273 K. Measurements conducted using the four-contacts method in DC (as in [11]) demonstrated significant hysteresis in Volt-Ampere Characteristics (VAC), and the time that needed to reach equilibrium current values (resistivity) was several hours. This behavior is characteristic for systems representing an electrochemical capacitor [10, 12]. Thus, close to the electrode space charge is formed associated with the migration of protons to the electrodes of the cell in the layer of adsorbed water. The typical process of relaxation of the proton migration, i.e. the presence of ionic components, when switching on and off of the power (voltage) supply is presented in Fig. 1.
Therefore, all subsequent measurements were performed in the frequency range $10^{3}-10^{4} \mathrm{~Hz}$, by using the phasesensitive (lock-in) microvoltmeter $232 \mathrm{P}$ Unipan at drive signal amplitude of $50 \mathrm{mV}$. In the present study, the results of measurements taken only for the frequency $1 \times 10^{3} \mathrm{~Hz}$ are presented, since the results obtained for other frequencies are almost identical.

\section{Results and discussion}

Figure 2 shows the temperature dependence of the real part of the impedance of the sample in $\ln \mathrm{R}-1 / \mathrm{T}$ coordinates, measured at a frequency of $1 \times 10^{3} \mathrm{~Hz}$. Maximum signal of the phase-sensitive voltmeter corresponds to zero phase difference of the excited and the reference voltage, which corresponds to the measurement of the real part of the impedance of the sample.

Complete crystallization of water occurs at temperatures near $230 \mathrm{~K}$. The temperature dependence of the resistance shows an Arrhenius behavior with the characteristic activation energy $0.21 \mathrm{eV}$ at temperatures above $0{ }^{\circ} \mathrm{C}$ and $0.38 \mathrm{eV}$ at temperatures below $0{ }^{\circ} \mathrm{C}$. In the latter case, an increase in the activation energy could be related to the fact that the transport in the system ice plus water requires more energy. The absolute values of the activation energy in general are similar to those obtained in previous studies [10], but there are some differences from the results of [9-11]. In previous studies [9, 10], a rather sharp change was observed in the impedance in the phase transition water-ice in nanoporous $\mathrm{Al}_{2} \mathrm{O}_{3}$.

Such a leap of conductivity in the phase transition in the system silicon dioxide-water was previously determined [11]. At the same time in the system titanium dioxidewater in the possible phase transition interval no anomalies were observed and the entire interval of temperatures above and below $0{ }^{\circ} \mathrm{C}$ characterized by a single activation
Fig. 1 Time dependence of the voltage of the sample at: $\mathbf{a}-\mathrm{ON}$ and $\mathbf{b}$ OFF regimes of the power (voltage) supply in a typical mode for measuring VAC $\left(\mathrm{R}_{\text {restricting }} \gg \mathrm{R}_{\text {sample }}\right)$
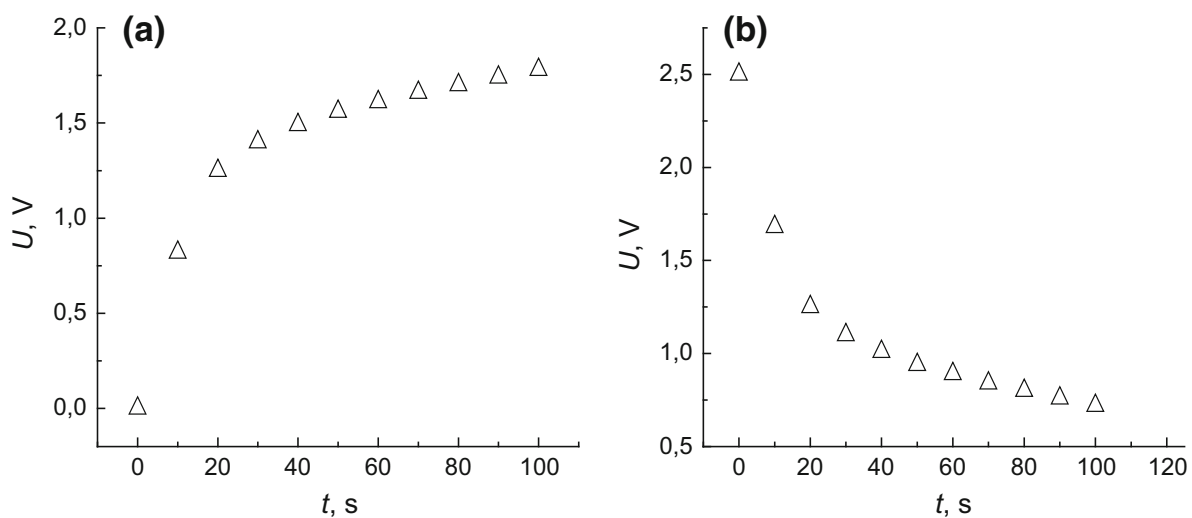


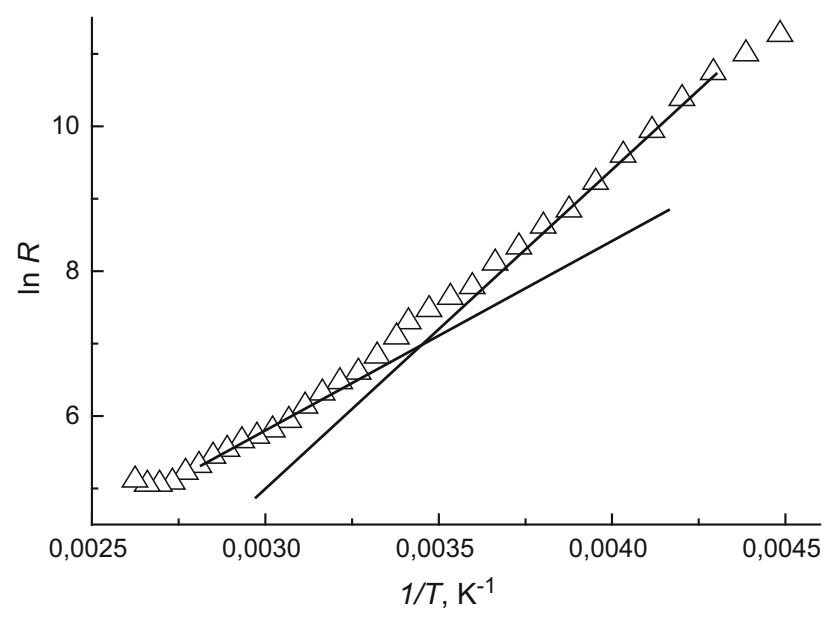

Fig. 2 Plot of temperature dependence of the real part of the impedance of the sample in $\ln R-1 / \mathrm{T}$ coordinates

energy of the charge transport $\sim 1 \mathrm{eV}$ [9]. This behavior of temperature dependences of the electric transport, according to previous work [9] may be related to the possible influence of the large value of the dielectric constant of $\mathrm{TiO}_{2}$, which causes a "structuring" effect on the dispersed in nanopores water and the formation of less "mobile" grid of hydrogen-bonded water molecules in the pores.

It is seen that when moving from $\mathrm{SiO}_{2}$ to $\mathrm{TiO}_{2}$, which corresponds to a conductivity jump smearing at the phase transition, the dielectric permittivity is growing $\left(\mathrm{SiO}_{2}\right.$ : 3.5-4 [25]; $\mathrm{Al}_{2} \mathrm{O}_{3}: 10$ [25]; $\mathrm{CeO}_{2}: 20$ [26, 27]; $\mathrm{TiO}_{2}: 25$ [28]) for the same size of the nanopores, $15-20 \mathrm{~nm}$. Interestingly, only for $\mathrm{CeO}_{2}$ a change in the activation energy is observed, as for the $\mathrm{TiO}_{2}$ peculiarities are completely absent.

\section{Conclusions}

On the temperature dependence of the conductance of the nanoporous cerium dioxide with adsorbed water there are no sudden changes and it is characterized by varying only the activation energy of proton transport above and below the temperature of the water-ice transition. Thereby, the most suitable nanoporous oxides to be used as humidity sensors, are those with a small dielectric permittivity.

Open Access This article is distributed under the terms of the Creative Commons Attribution 4.0 International License (http://crea tivecommons.org/licenses/by/4.0/), which permits unrestricted use, distribution, and reproduction in any medium, provided you give appropriate credit to the original author(s) and the source, provide a link to the Creative Commons license, and indicate if changes were made.

\section{References}

1. Y. Daiko, J. Sol-Gel Sci. Technol. 70, 172 (2014)

2. E. Chiavazzo, M. Fasano, P. Asinari, P. Decuzzi, Nat. Commun. 5, 4565 (2014)

3. K. Hatakeyama, M.R. Karim, C. Ogata, H. Tateishi, T. Taniguchi, M. Koinuma, S. Hayami, Y. Matsumoto, Chem. Commun. 50, 14527 (2014)

4. E.Z. Pina-Salazar, K. Kaneko, Colloids Interface Sci. Commun. 5, 8 (2015)

5. K.D. Kreuer, Chem. Mater. 8, 610 (1996)

6. A. Bogdan, M. Kumala, N. Avramenko, Phys. Rev. Lett. 81, 1042 (1995)

7. E. Hensen, M. Stocker, R. Schmidt, J. Phys. Chem. B 100, 2195 (1996)

8. J.M. Baker, J.C. Dore, P. Behrens, J. Phys. Chem. B 101, 6226 (1997)

9. F.A. Korolev, L. Nosova, V.G. Kytin, S.N. Kozlov, Phys. Stat. Sol. (a) 202, 1096 (2005)

10. F.A. Korolev, V.G. Kytin, S.N. Kozlov, Vest. MSU Ser. 3 Phys. Astron. 4, 58 (2005). (in Russian)

11. E.N. Luk'yanova, S.N. Kozlov, JTF Lett. 27, 1 (2001). (in Russian)

12. G.S. Bordonskyi, A.O. Orlov, FTT 56, 1575 (2014). (in Russian)

13. Y. Yao, X. Chen, J. Zhu, B. Zeng, Z. Wu, X. Li, Nanoscale Res. Lett. 7, 363 (2012)

14. H. Wang, A. Chroneos, U. Schwingenschlögl, J. Chem. Phys. 138, 224705 (2013)

15. M.J.D. Rushton, A. Chroneos, S.J. Skinner, J.A. Kilner, R.W. Grimes, Solid State Ion. 230, 37 (2013)

16. M.J.D. Rushton, A. Chroneos, Sci. Rep. 4, 6068 (2014)

17. R.W. Grimes, G. Busker, M.A. McCoy, A. Chroneos, J.A. Kilner, S.P. Chen, Ber. Bunsen. Phys. Chem. 101, 1204 (1997)

18. D. Parfitt, A. Chroneos, A. Tarancon, J.A. Kilner, J. Mater. Chem. 21, 2183 (2011)

19. A. Kushima, B. Yildiz, J. Mater. Chem. 20, 4809 (2010)

20. I.D. Seymour, A. Chroneos, J.A. Kilner, R.W. Grimes, Phys. Chem. Chem. Phys. 13, 15305 (2011)

21. I.D. Seymour, A. Tarancon, A. Chroneos, D. Parfitt, J.A. Kilner, R.W. Grimes, Solid State Ion. 216, 41 (2012)

22. M.L. Traulsen, H.H. Ingelsten, K.K. Hansen, J. Phys. Chem. A 116, 2497 (2014)

23. J.A. Felton, M. Ray, S.E. Weller, J.O. Kafader, C.C. Jarrold, J. Phys. Chem. A 118, 9960 (2014)

24. V.K. Ivanov, A.B. Scherbakov, A.E. Baranchikov, V.V. Kozik, Nanocrystalline Cerium Dioxide-Properties, Preparation, Application (Iz-vo TSU, Tomsk, 2013). (in Russian)

25. I.S. Grigor'ev, E.Z. Meilikhov (eds.), Physical Quantities: Handbook (Energoatomizdat, Moscow, 1991). (in Russian)

26. V.A. Ogorodnik, G.A. Galina, G.I. Kal'naya, N.M. Prishchepa, Visn. NTUU KPI Ser. Radioteh. Radioaparatobuduv. 30, 82 (1993). (in Russian)

27. S. Boskovic, S. Zec, G. Brankovic, Ceram. Int. 36, 121 (2010)

28. G. Garcia-Belmonte, V. Kytin, T. Dittrich, J. Bisquert, J. Appl. Phys. 94, 5261 (2003) 